\title{
TWO UNKNOWN CASES OF PRINTED INCIDENTAL MUSIC IN THE SIXTEENTH- AND SEVENTEENTH- CENTURY ITALIAN THEATRE
}

\author{
IVANO CAVALLINI \\ Università di Palermo
}

\begin{abstract}
Izvleček: Francesco Contarini je svojo pastoralo La finta Fiammetta, ki je bila izvedena $v$ Padovi skupaj z intermediji v pustnem času 1610, izdal pod pokroviteljstvom kardinala Scipiona Borgheseja. Drugo izdajo (1611) - posvečeno istemu kardinalu-spremlja ločena knjižica $z$ intermediji, ki pa so posvečeni beneškemu ambasadorju pri svetem sedežu v Rimu Giovanniju Mocenigu. $V$ luči »vojne prepovedanega" med Rimom in Benetkami (1606-1607) je politična vloga teh tiskov očitna. Drugega od štirih intermedijev "rappresentati nella finta Fiammetta" (1611) z naslovom La lotta di Hercole con la Morte je leta 1624 Innocentio Vivarino uglasbil kot monodično delo s spremljavo dveh violin (Madrigali concertati a due e tre voci et a voce con violini e sinfonie) za lika Alkestide in Apolona.
\end{abstract}

Ključne besede: Francesco Contarini, La finta Fiammetta, pastorala, priložnostna glasba, intermedij, Alkestida, Innocentio Vivarino.

\begin{abstract}
Francesco Contarini published his pastoral La finta Fiammetta, staged in Padua with a set of intermedi in carnival 1610, under the patronage of Cardinal Scipione Borghese. A second edition (1611) - likewise dedicated to the cardinal - is accompanied by a separate libretto containing intermedi dedicated to Giovanni Mocenigo, Venetian ambassador at the Holy See in Rome. Against the background of the "War of the Interdiction" between Rome and Venice (1606-1607) the political role of these books is evident. The second of the four Intermedi rappresentati nella finta Fiammetta (1611), entitled La lotta di Hercole con la Morte, was set to music in 1624 by Innocentio Vivarino (Madrigali concertati a due e tre voci et a voce con violini e sinfonie) as a monodic composition for Alcestis and Apollo with an accompaniment of two violins.
\end{abstract}

Keywords: Francesco Contarini, La finta Fiammetta, pastoral drama, incidental music, intermedio, Alcestis, Innocentio Vivarino.

Despite the large quantity of monody and polyphony performed in the sixteenth-century Italian theatre, only a small amount was printed. Any kind of incidental music, either on stage or between the acts, was considered an ephemeral component of the production, on a par with scenery and illumination. In this context, the case of Florence constituted an exception. The Grand Dukes of Tuscany conceived theatre as a political tool expressing their power and wealth, and as a way to celebrate their modern feeling for stage production. This is the reason why recovering Florentine spectacles is easy enough today: the texts of comedies and pastorals, their scenarios, their stage directions and their music 
were published and disseminated widely in Italy and abroad. In contrast, Mantua, Venice, Ferrara, Rome and Naples, equally involved with theatrical activities, were less energetic than Florence in publicizing their music.

Current musicology, following the lead set by Wolfgang Osthoff, Nino Pirrotta and some other eminent scholars such as Francesco Luisi, strives to establish the rules of music written for the theatre through an analysis of its relationship to the text. ${ }^{1}$ Unfortunately, a lack of information on the use of many works prevents musicologists from establishing whether or not they were employed in the theatre.

In this collection of papers about the circulation of music books, I would like to present two case studies showing the connection between books containing, respectively, dramas, intermedi and music. The first study reveals an unconventional use for the polyphony printed before the text of a pastoral: not in the manner of a quotation of a French chanson, a canzonetta or a madrigal in order to lend a touch of realism to the acts, as occurred in contemporary comedies, but in this instance with the aim of paying tribute to two noble guests. The second study brings to light the intriguing story of a pastoral staged in Padua, a subsequent, unforeseen edition of its intermedi prepared by its author for a second event in Venice and, finally, the discovery of its music, which was included in a book of monodies published fourteen years later and lacking any reference by the author to the earlier spectacles.

In honour of Gesualdo da Venosa and probably of Alfonso Fontanelli, both of whom were noblemen and composers, Illuminato Ferazzoli staged in 1594, in Lugo di Romagna, the pastoral entitled Fileno. Like Torquato Tasso in his famous Aminta (1573), this dramatist introduced a chorus at the end of each act. But unlike Tasso, who had rethought the role of the chorus with the purpose of avoiding the addition of extraneous musical spectacles, Ferazzoli included intermedi within his drama. This decision exemplified the failure of the project, conceived by the literati, to regulate pastoral drama by providing an epigrammatic, self-sufficient finale in imitation of the chorus of ancient tragedy. In a similar spirit, and probably against the wishes of its author, Aminta was staged in 1579 at the court of Ferrara with the addition of some intermedi; the same happened later in Florence at the instigation of the ladies of the court (1590). ${ }^{2}$

The conclusion of the fourth act of Fileno does not follow a regular pattern. It consists of a chorus followed by an intermedio, and after it comes a new chorus. As indicated by the stage direction "Tutti cantano Oratio Vecchi sulla Selva," the stanza Ecco nuncio di gioia is the eight-voice dialogue found in Vecchi's Selva di varia ricreatione (1590). The reference to a singing chorus of shepherds and nymphs is an unexpected instance of the use of music printed earlier than the drama and without any connection to it, which produces the irregular sequence chorus - intermedio - chorus. In my opinion, this interpolation is the result of a friendship between Vecchi and Fontanelli. ${ }^{3}$

1 Osthoff, Theatergesang und darstellende Musik; Pirrotta, Li due Orfei; Luisi, Il Caritesio.

2 The matter is examined in Cavicchi, "Immagini e forme," 46-47; see also Solerti, "Laura Guidiccioni Lucchesini," 808-809.

3 On this subject, see Cavallini, "Nuove riflessioni." 
There is one other unknown case that illustrates the difficulty of reconstructing a spectacle on the basis of surviving sources: or, rather, of assembling in complete form the text of the drama, the text of the intermedi and the latter's music, published later and without a declared connection with those intermedi.

The renowned Venetian philosopher and dramatist Francesco Contarini, whose biography remains obscure, is easily confused with other writers of the same name. ${ }^{4}$ For this reason, it is worth pointing out that he was the natural son of the patrician Taddeo Contarini, as recorded in certain of this writer's works: the philosophical treatise De Deo (1594); ${ }^{5}$ the dedication of the pastoral play La fida ninfa (1598), written in honour of the Grand Duke of Tuscany, Ferdinando de' Medici ("May my Fida ninfa come out into the world under the protection of the glorious name of Your Serene Highness, [...] to whom I myself, the excellent Mr. Tadeo, my father, and my entire family humbly pledge devotion"); ${ }^{6}$ and the dedicatory letter addressed to the Doge of Venice, Marcantonio Memmo, accompanying his tragedy Isaccio (1615), which is signed "Francesco Contarini di f[u] Tadeo." Moreover, besides being a prolific author of theatrical pieces, Contarini was active as a lecturer at the University of Padua. His well-known pastoral La fida ninfa, dedicated to Francesco Ferdinando, was published (either under the already mentioned title or its equivalent, Darinello) at least ten times by different printers from 1598 to the early seventeenth century. However, the seventeenth-century editions are dedicated exclusively to Antonio Priuli, Doge of Venice. ${ }^{7}$ Appointed principe of the Accademia Serafica in Venice, Contarini was a member also of the Accademia Olimpica in Vicenza and the Accademia dei Ricovrati in Padua, and an honorary member of the Accademia Filarmonica in Verona, as attested by his philosophical lecture in the form of an apology entitled Oratione [...] alla virtuosissima Academia Filarmonica di Verona nell'essere stato accettato Academico (1621). This volume was published in Verona by the above-mentioned Accademia Filarmonica; more importantly, it displays on its title page the famous figure of a Siren symbolizing the harmony of the Cosmos in which music participates as a harmony among other kinds of harmony.

Although his name is linked to many learned societies, Contarini maintained his closest ties with the Accademia dei Ricovrati founded in Padua in 1599. Two editions of his Fida ninfa were published in 1598-1599 by Francesco Bolzetta, printer to the Paduan academy; in the years 1600-1601 and 1608-1609 Contarini acted as secretary to the Ricovrati, and in 1601 he published numerous madrigals in praise of Federico Baldissera Bartolomeo Corner, the academy's founder, under the title of Madrigali di Francesco Contarini academico Olimpico e Ricovrato dedicati all'illustrissimo et reverendissimo

4 Some references to Contarini's biography are collected on the website www.idt.paris-sorbonne. fr/corpus.

5 Francesci Contareni Thadaei patritii veneti filii, philosophiae, iuris utriusque et sacrae theologiae doctoris, de Deo et de his quae effluxerunt a Deo.

6 "Esca dunque nel mondo la mia Fida ninfa sotto la scorta del glorioso nome di Vostra Altezza Serenissima, il quale quasi benigna stella di Giove impressole in fronte la potrà rendere ad ognuno amabile e graziosa: insieme con la quale io stesso, e'l clarissimo signor Tadeo mio padre, e tutta la mia famiglia, umilmente se le doniamo [...] 10 marzo 1598." Contarini, La fida ninfa, 7b.

7 The relevant editions are listed in Rees, "Satyr Scenes in Early Modern Padua," 48n31. 


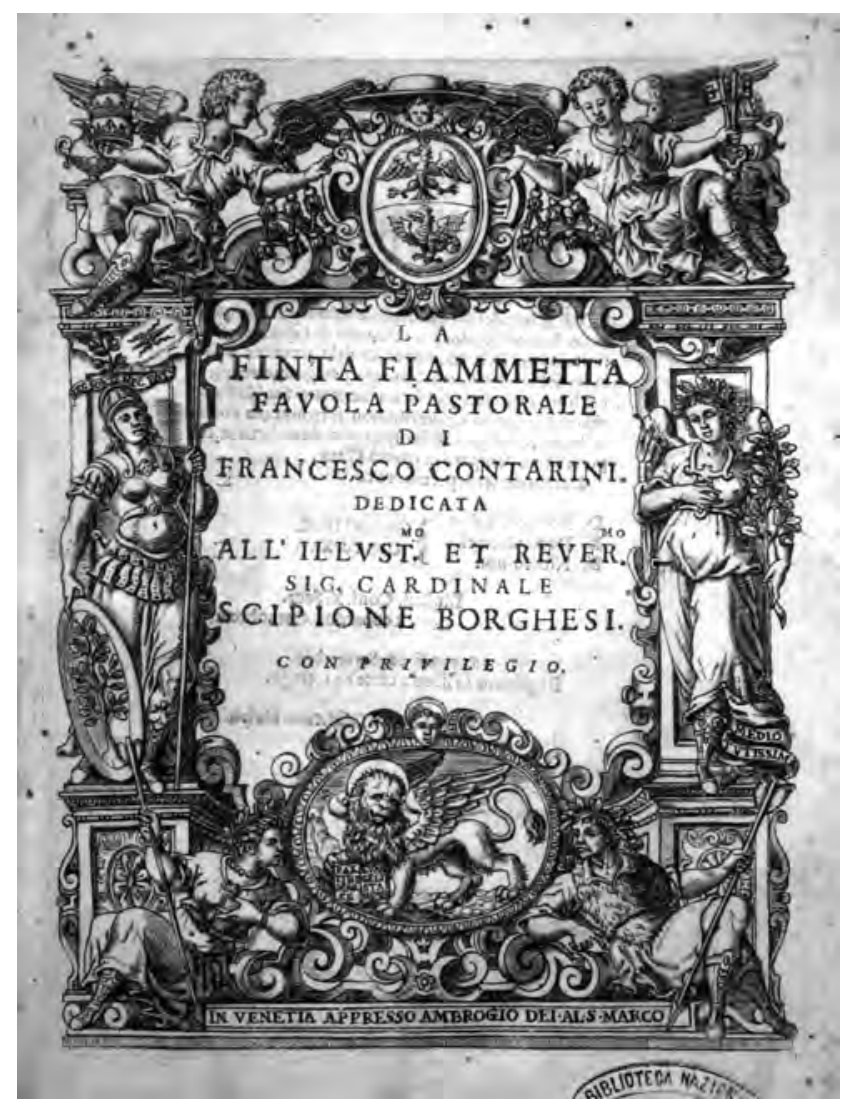

Figure 1 Francesco Contarini, La finta

Fiammetta (1610); title page of the first edition (Venice, Biblioteca Nazionale Marciana, Dramm. 0072; reproduced with kind permission).

sig. Federico Cornaro gran Comendator di Cipri, Abbate di Vidore e Chierico di Camera (1601). ${ }^{8}$ Finally, he wrote, on behalf of the Paduan academy, a valedictory oration for Tomaso Contarini, the mayor and governor of the city: Oratione di Francesco Contarini per nome dell'Academia Ricovrata all'illustrissimo signor Tomaso Contarini, cavalier, conte del Zaffo, e podestà di Padova nella sua partenza (1609).

In autumn 1609 Count Egano Thiene, a jurist responsible for the students of Law at the University of Padua, proposed the writing of a pastoral play for the recreation of these young scholars, who had grown weary of their studies: "Proposuit idem [Count Thiene] quod pro recreandis animis d. scolarium ob assiduum studium laxatis in Carnisprivii proximo venturo debeat quedam nova pastoralis comoedia." ${ }^{\circ}$ Contarini was accordingly requested to write the pastoral La finta Fiammetta (see Fig. 1), which was performed in Padua during carnival 1610, as recorded by the printer Ambrogio Dei in a letter that quotes the name of Egano Thiene but does not give the place of performance: "This pastoral [...]

8 Maggiolo, I soci dell'Accademia Patavina, 78.

9 Recorded on 12 December 1609. See Brunelli, I teatri di Padova, 67. 
was staged during the last carnival by students of Law in this noble University, under the patronage of Count Egano Thiene." ${ }^{10}$

La finta Fiammetta is dedicated to Scipione Borghese, the young nephew of Pope Paul V, who appointed him Cardinal in 1605. The dedicatory letter is dated 24 October 1610; immediately afterwards, on 25 October, Scipione was also appointed Archbishop of Bologna, being consecrated by the Pope in an official ceremony held at the Cappella Sistina on 8 December. ${ }^{11}$ It is still unclear to me whether the pastoral came into being under the patronage of Borghese himself, or whether it was an unofficial tribute paid to the Cardinal by the Venetian government via Contarini's play. Anyway, what is incontestable is the political role of the first and second editions. At the top of the title page of the first edition there appear the insignia of the Borghese family, and at the bottom the winged lion of Saint Mark. In the second edition, printed carelessly probably during the early months of 1611, these emblems are replaced by a single coat of arms - that of the Cardinal's nephew - while the symbols of Venice are omitted. The new edition, with the title of $L a$ finta Fiammetta, favola pastorale di Francesco Contarini. Dedicata all'illustrissimo et reverendissimo signor cardinale Scipione Borghesi con gl'Intermedi aggiunti in questa seconda impressione (1611), reprints the dedicatory epistle for Borghese (see Fig. 2). ${ }^{12}$ This second edition of the pastoral drama is connected with a contemporary but separate libretto of intermedi dedicated to Giovanni Mocenigo: Intermedi rappresentati nella finta Fiammetta di Francesco Contarini. Dedicati all'illustrissimo et eccellentissimo sig. Giovanni Mocenigo ambasciatore veneto a n. s. papa Paolo V (1611; see Fig. 3). On the title page of the Intermedi the previous Borghese coat of arms is replaced by the lion of the Venetian Republic, since from 1609 to 1612 Giovanni Mocenigo held the post of Ambassador to the Holy See in Rome ("ambasciatore ordinario alla Corte di Roma"). ${ }^{13}$ Contarini's dedication draws attention to the delicate role played by Mocenigo, who in 1611 sent the Venetian Senate a detailed relazione, where the Ambassador describes the nepotism and absolutism of Pope Paul V: "The Cardinal is thirty three years old [...] he possesses the authority and honours proper to the Pope's nephews, and in consequence, the ambassadors, after any audience with the Pope, are obliged to inform the Cardinal about the matters discussed." ${ }^{14}$

To summarize, there were two dedicatees: Borghese for the première in Padua

10 “Ai benigni lettori Ambrogio Dei [...]. Questa pastorale, che con tanto applauso, et illustrissima pompa, fu rappresentata il carnevale passato in Padova dalla nobilissima università de' signori legisti di questo studio, sotto'l favorito sindicato del molto illustre signor cont'Egano Tiene, era da un numero di quasi infiniti spiriti pellegrini istantemente desiderata e dimandata." Contarini, La finta Fiammetta (1610).

${ }^{11}$ Castronovo, "Borghese Caffarelli, Scipione."

12 Printed in Venice by Ambrogio Dei in 1611.

${ }^{13}$ See www.storiadivenezia.net/sito/testi/Antonibon.pdf.

14 "Questo principe è carissimo ed amatissimo dal Pontefice, e nella persona sua sono riposte tutte le speranze della grandezza della casa Borghese. Il cardinale è in età di 33 anni, ha nell'apparenza tutta l'autorità ed onori che sogliono avere li nepoti dei Pontefici, perché tutti gli ambasciatori dopo l'udienza vanno a lui e gli comunicano ogni trattazione." See Relazioni degli stati europei, 91-110. 


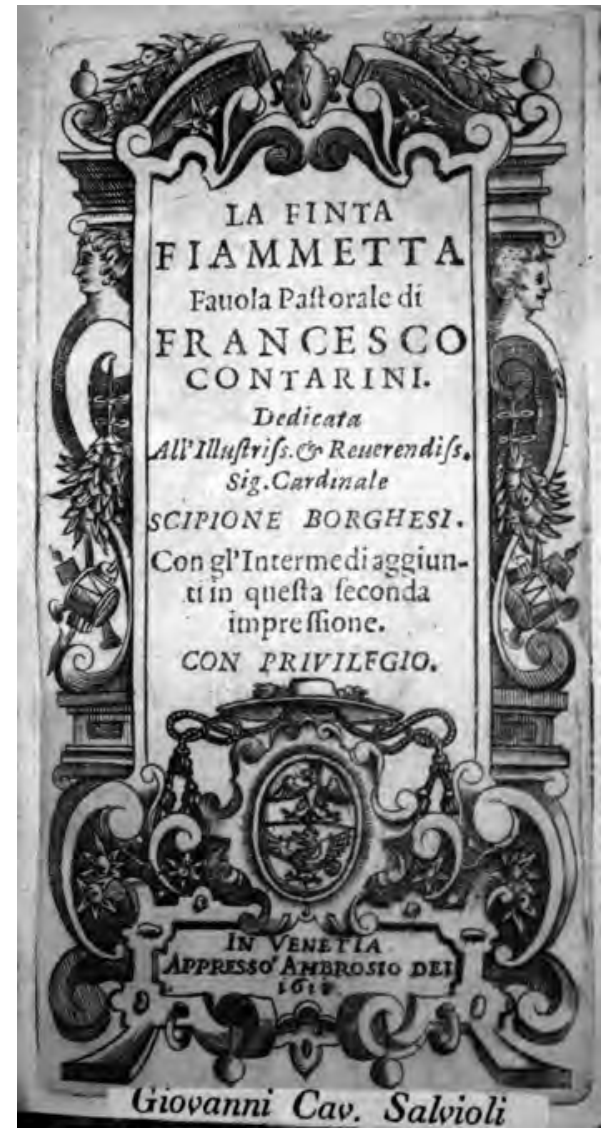

Figure 2 Francesco Contarini, La finta Fiammetta (1611); title page of the second edition (Venice, Biblioteca Nazionale Marciana, Dramm. 1988; reproduced with kind permission).

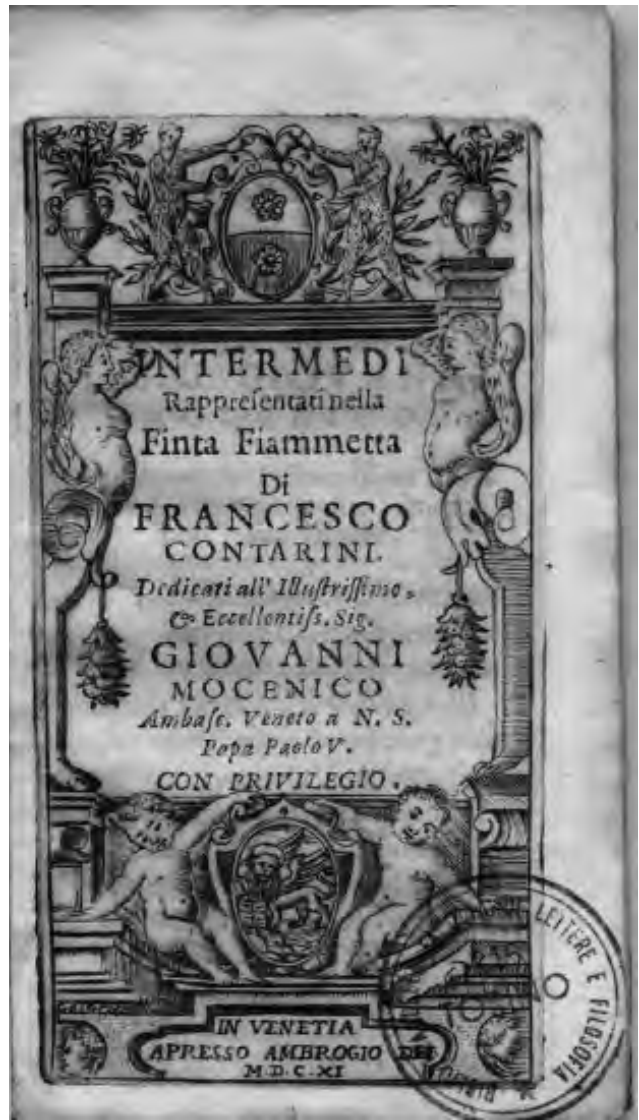

Figure 3 Francesco Contarini, Intermedi rappresentati nella finta Fiammetta (1611); title page (available online: www.archive.org).

with intermedi, which were printed, later in 1611, in honour of Mocenigo; and once more Borghese for the second edition of the pastoral drama, plus Mocenigo only for the intermedi between the acts. The second edition was probably prepared for a revival in a Venetian palazzo. ${ }^{15}$ The title of a parallel edition of these spectacles, printed by Dei with identical pagination, dedication and content, states that they had been "staged in Padua:" Intermedi rappresentati nella finta Fiammetta in Padoa. Di Francesco Contarini (1611; see Fig. 4). As confirmation of this event we have the above-mentioned second edition of

${ }^{15}$ On theatre and music in Venice at the end of the sixteenth century, see Solerti, "Le rappresentazioni musicali." 
La finta Fiammetta, where the printer informs readers that, having been instructed to reprint the pastoral, he had needed to ask Contarini for permission to publish it together with the intermedi, which had been successfully performed in Padua. ${ }^{16}$

At this juncture, it needs saying that it was not the custom then in Venice to print intermedi and musical scores, so La finta Fiammetta already provides an exceptional case. Contarini, I suppose, was being supported by Mocenigo at the time when he entered the Pope's court as a diplomat. With the intention of demonstrating Venice's positive feelings towards Cardinal Borghese, Mocenigo promoted a second performance of La finta Fiammetta three years after the so-called War of the Interdiction (1605-1607), a crisis that had arisen between the Roman Curia and the Republic on account of the tolerant attitude that Venice showed towards the Protestant lands of Europe. The casus belli was the refusal of Venice to turn over the civil trial of two priests to a clerical tribunal, as demanded by the Roman Curia. ${ }^{17}$ It would not be unreasonable to venture the hypothesis that the staging of the pastoral in Padua (and probably also in Venice) in honour of Cardinal Borghese, together with the inclusion of the intermedi celebrating Mocenigo's diplomacy, symbolizes

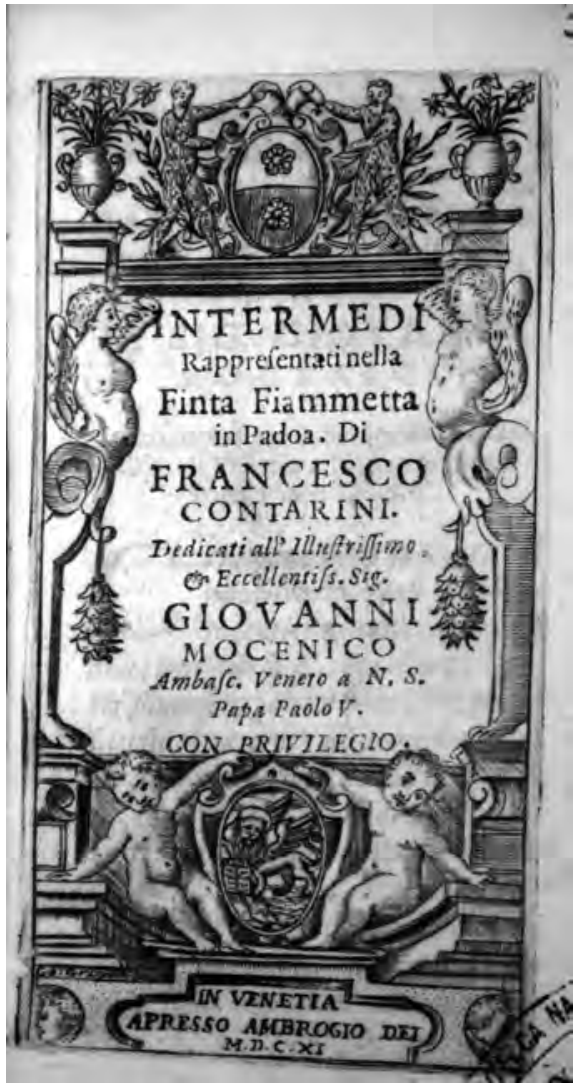

Figure 4 Francesco Contarini, Intermedi rappresentati nella finta Fiammetta in Padoa (1611); title page (Venice, Biblioteca Nazionale Marciana, Dramm. 3733; reproduced with kind permission). the reconciliation between the Vatican and the Venetian Republic. This interpretation makes sense of the joint presence of the Cardinal's insignia and the Venetian lion on the title page of the original wordbook of La finta Fiammetta. Unfortunately, only a chronicle describing the event would be able to confirm this hypothesis and explain this singular case of intermedi printed in Venice.

With regard to Contarini's theatrical essays, one may recall another staged performance with intermedi that took place in Venice. During the carnival of 1615 the Accademia dei

16 “Ai benigni lettori. Ambrogio Dei. [...] ho risoluto di farne questa seconda impressione, nella quale per darvi qualcosa di più, che nella prima non era, ho dall'autore quest'Intermedi ottenuti, che insieme con la favola furono in Padoa il passato carnevale con celebre apparato rappresentati." Contarini, La finta Fiammetta (1611).

${ }^{17}$ See the proceedings Lo stato Marciano durante l'interdetto. 
Generosi performed the tragedy Isaccio at the Patriarchal Seminary. Contarini's dedication emphasizes the elaborate apparati and marvellous intermedi ("regale apparato et con artificiosi et maravigliosi intermedi"). ${ }^{18}$ Despite the difficulty of finding the intermedi for this tragedy, we possess, as evidence of the important role of music in them, the prologue sung by Astrea to the accompaniment of a chitarrone ("Astrea. Prologo cantato in Chiterone"). ${ }^{19}$ There can be no doubt that Contarini's Isaccio was one of the most significant Venetian dramas of its time. Like that of many historically based tragedies with a lieto fine, a type very popular throughout the Venetian state, the plot of Isaccio recounts an episode that had occurred in Constantinople during the twelfth century: it is the story of the traitor Alessio, who usurps the imperial throne of his brother Isaccio, whom he kills. ${ }^{20}$ Thanks to help from Doge Dandolo, the true Alessio, Isaccio's son, assumes power in the eastern part of the realm. From an ideological point of view, Contarini's Isaccio symbolizes Venice's greatness and the wisdom of its policy. This tragedy, too, is supplied with intermedi in defiance of the theory of drama that permitted only the use of a "neoclassical" chorus singing in simple polyphony. ${ }^{21}$

The intermedi for La finta Fiammetta have a variety of subjects, all based on history or mythology: the building of Venice (L'edificatione di Venetia); ${ }^{22}$ the struggle of Hercules with Death (La lotta di Hercole con la Morte); ${ }^{23}$ Cupid's verdict on the controversy over love between Cleitophon and Arminda (Il contratto amoroso) ${ }^{24}$ and finally, a pièce à sauvetage in which Venus rescues Aeneas, under threat from Achilles (Abbattimento d'Achille e d'Enea) ${ }^{25}$ For each spectacle there is a synopsis, together with a great quantity of stage directions acting as a scenario. The second intermedio, La lotta di Ercole con la Morte, presents a variant of the story of Alcestis inspired by Euripides's tragedy. The characters are Apollo, Hercules, Death, Chorus of Citizens, Admetus King of Thessaly, and Alcestis, the wife of Admetus who sacrifices herself and by a heroic deed saves her husband. As a god, Apollo has the capacity to sing, whereas the other characters merely act, and Alcestis remains silent ("Alcestide regina sua moglie, la quale non parla"). ${ }^{26}$ This

${ }^{18}$ Contarini, Isaccio, 4.

${ }^{19}$ Ibid., 10.

${ }^{20}$ Mangini, "La tragedia e la commedia," 308, 323.

${ }^{21}$ Luisi, "Musica e tragedia."

${ }^{22}$ Contarini, Intermedi rappresentati nella finta Fiammetta, 5-19.

${ }^{23}$ Ibid., 20-39.

${ }^{24}$ Ibid., 40-55.

${ }^{25}$ Ibid., 56-71.

${ }^{26}$ The original synopsis and scenario run as follows: "Argomento. Apollo sbandito dal Cielo ricorse al re Admeto, da cui fu lasciato sotto rusticane spoglie a guardare gli armenti in riva al fiume Anfriso. Ora giunta essendo l'ora fatale al re, Apollo in ricompensa del ricevuto beneficio, ottenne dalla Parche che la vita gli prolungassero; ma con patto da loro aggiunto, mentre alcuno fosse de' suoi più congiunti, che per lui volesse morirsi. La sola moglie si trovò che volesse farlo, onde, sendo ella morta per lui in quel tempo che se ne celebravano le pompe funebri, Hercole vi arrivò, et volendo alloggiare col re Admeto, ei gli celò la cagione della mestizia per non contristare l'amico: ma Apollo rivelando ad Hercole la cortesia del re, lo sprona col suo esempio a mostrarsegli grato dell'ospizio, et a ritornare in vita la regina; il che egli prontamente essequisce, per che combattendo con la Morte ne riporta gloriosa vittoria. Euripide nell'Alcestide". 
Figure 5 Innocentio Vivarino, Madrigali concertati a due e tre voci (1624); title page (Vienna, Österreichische Nationalbibliothek, Musiksammlung SA. 79.C.44; reproduced with kind permission).

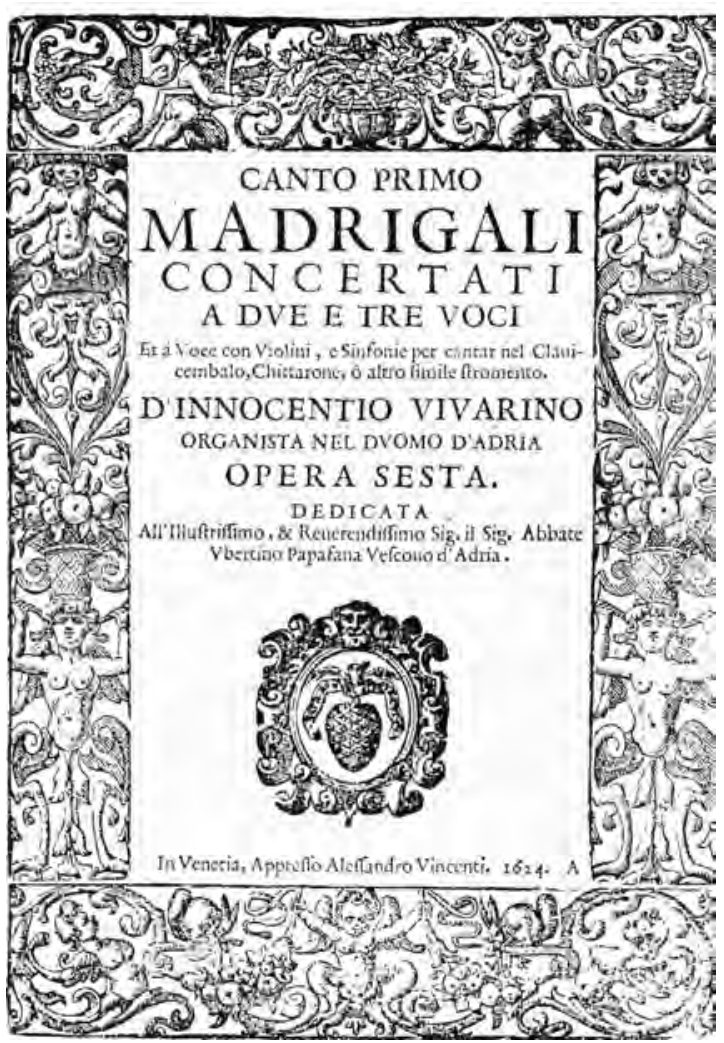

is in accordance with the rules of verisimilitude observed from the time of Poliziano's Fabula di Orfeo up to the time of the earliest operas. The setting is the city of Phaere, the royal residence of King Admetus. On one side of the stage there is Hades, from which emerges Death, who will fight with Hercules. On the other side, assuming the function of a deus ex machina, there is Apollo, who sings on a cloud in front of Hercules ("Apollo comparve nella nube in aria, et tutto in un tratto comparve Hercole armato su la scena, et Apollo cantò nella lira"). The god rouses Hercules and instances some of his twelve labours: those of the Nemean Lion, the Lernaean Hydra, the Erymanthian Boar, and the Garden of the Hesperides. ${ }^{27}$

Fourteen years later, Innocentio Vivarino, maestro di cappella at the Cathedral of Adria near Padua and Venice, recycled the music for this intermedio in his Madrigali

"Maniera della rappresentazione di questo intermedio. Finito il secondo atto della favola, e cambiata velocemente la scena, dall'una parte fu veduta la città regia di Tessaglia, ove in un lato era un sepolcro; dall'altra parte si vide l'aspetto di una città quasi tutta ardente; presso a cui fu poi veduto, quando ora ne fu, aprirsi la terra, et da una bocca d'inferno uscire la Morte. Appena erasi veduta la scena mutata, che si vide venire anche Apollo in una nube per quel fine, per lo quale egli fu a cantare introdotto nell'intermedio, il quale finito, tosto la prima scena pastorale si rivide essere tornata."

${ }^{27}$ Contarini, Intermedi rappresentati nella finta Fiammetta, 26. 
concertati a due e tre voci et a voce con violini e sinfonie per cantar nel clavicembalo, chitarrone o altro simile strumento d'Innocentio Vivarino, organista nel Duomo d'Adria. Opera sesta (1624; see Fig. 5). ${ }^{28}$ Unfortunately, Vivarino does not provide any explanation for the monody of Apollo inserted at the end of the book. In this connection, one should bear in mind that composers of the time were rarely attracted by the texts of intermedi. They more usually set to music the poems of Petrarch, Bembo, Tasso, Guarini and other famous authors; moreover, intermedi were by definition unrepeatable events. So one may confidently say that Vivarino and his other colleagues were commissioned by someone else to write the music for Contarini's verses. Perhaps Vivarino became free to use this music on his own behalf after the death of the dramatist. That said, the dedicatee of the Madrigali concertati - the Bishop of Adria, Ubertino Papafava, a member of a well-known patrician family of Padua - would not have looked kindly on any reference to events of the past that had not concerned him. In this connection, we need to examine carefully the sequence of events. On 28 May 1623 Ubertino Papafava was appointed bishop of Adria, but he took up this position officially only one year later, on 28 April $1624 . .^{29}$ Vivarino had already signed his madrigals one month earlier, on 15 March, referring to Papafava in the dedicatory letter as a patron and future protector. But on the title page Papafava is explicitly named Abbot and Bishop of Adria. So the likelihood is that the collection was approved by Papafava (with an assurance to the composer of a regalo) a short time before his consecration as Bishop at the end of April 1624.

As in Contarini's original source, in Vivarino's book of madrigals it is Apollo who sings. However, unlike Contarini, the composer adds at the beginning of his version a monologue for Alcestis as evidence of the queen's sacrifice. Nevertheless, the identity of the characters (not revealed in the partbooks) is never clarified, nor is the story of Alcestis related. Table 1 gives the incipits of the stanzas sung by the soprano and the instrumental interludes in Vivarino's version:

\section{Table 1}

1 Che'l mio amor, che'l mio ben, che'l mio sostegno, S., 2 vn., b.c. (stanza for Alcestis added by Vivarino)

2 Sinfonia prima, 2 vn., b.c.

3 O magnanimo Alcide, S., b.c. (Apollo)

4 Sinfonia Seconda, 2 vn., b.c. ("doi violini in loco di risposta seguono”)

5 Pugnar ora convienti, S., b.c. (Id.)

6 Sinfonia Terza, 2 vn. b.c. (“doi violini seguono”)

7 Gliela torrai di man, pugna e travaglia, S., b.c. (Id.)

8 Si replica la Prima [Sinfonia] (“doi violini”: repeat of the first ritornello)

9 O magnanimo eroe vinto hai la morte, S., 2 vn., b.c. (Id.)

10 Si replica la Terza [Sinfonia] (repeat of the third ritornello)

${ }^{28}$ An example of this collection, published in Venice by Alessandro Vincenti, is preserved in the music collection of the Österreichische Nationalbibliothek, Vienna. On Vivarino (ca. 1575-1626) and his oeuvre, see Cavallini, "Note biografiche."

${ }^{29}$ See Serie cronologica dei vescovi di Adria, 38-39. 
In Table 2, I compare the original intermedio with Vivarino's edition. Only the stanzas set to music by the composer are given in full; for the other stanzas, acted without music, the incipit alone is transcribed. Stage directions are all omitted, except for the words indicating the disappearance of Apollo into the cloud:

\section{Table 2}

\section{Alcestis [text and music by Vivarino]}

Che'l mio amor, che'l mio ben, che'l mio sostegno,

a nove cure involto,

faccia da me partita,

non mi toglie la vita.

Ma che nella più insolta e oscura notte,

con disagio di lume o di Diana,

Venus, the Morning Star

assorga da le piume e si allontana,

piume $=$ bed

in così dura sorte

fuggir, ohimè, non mi lice la morte.

\section{Apollo [set to music by Vivarino]}

0 magnanimo Alcide

Hercules

che fai, che pensi a gloriose imprese?

Ti desta Apollo e lieto il ciel t’arride.

\section{Hercules [omitted by Vivarino]}

o Febo, o santo nume [...]

\section{Apollo [set to music by Vivarino]}

Pugnar ora convienti,

non con aspri serpenti,

non con fiera Nemea,

The Nemean Lion

non con cingial menalio, o con arpie,

The Erymanthian Boar

non con esperio drago,

The Garden of the Hesperides

non con uomo mortale al tuo valore,

non più tentate vie

vengon mutate in sorte,

t'apparecchia la pugna con la morte:

Ella ha tolto la moglie al rege Admetto,

Admetus, King of Phaere in Thessaly

tosto ora tu gli la rendi viva

pria che squallida torna all'altra riva.

The river Acheron or Styx?

\section{Hercules [omitted by Vivarino]}

Ospite aventuroso [...]

\section{Apollo [set to music by Vivarino]}

Gliela torrai di man, pugna e travaglia, 
al sepolcro verrà tu qual'attendi

e contra lei t’affronta, osa e contendi

la funeral vivanda al dente ingordo.

Io'l marito l'ho tolto,

Apollo vs Artemis

le avrai tu la consorte anco ritolto?

consorte $=$ Alcestis

Ribonderà d'Anfrino il lido intorno

The river Amphrysus

Alcide egual al portator del giorno.

(Stage direction: "Qui tacque Apollo e si rinchiuse nella nube, la quale non disparve, ma stette ferma, et Hercole così rispose".)

\section{Hercules [omitted by Vivarino]}

0 luminoso divo [...]

\section{Chorus of citizens [id.]}

0 sfortunato regno $[\ldots]$

Hercules [id.]

Cessino i pianti omai [...]

Chorus [id.

Ahi, qual novo terror s'apre la terra? [...]

Hercules [id.]

Nel timor vi tocchi, ombre o fantasime [...]

Chorus [id.]

A gran cose t'accingi, Hercole invitto [...]

\section{Hercules [id.]}

Fuggite voi, fuggite anime vili [...]

\section{Death [id.]}

Or non potrai tu, Apollo, [...]

\section{Hercules [id.]}

Non godrai queste vittime da Alcide [...]

\section{Death [id.]}

Osi tu contrastar, Hercole audace? [...]

\section{Hercules [id.]}

Io son mortal, ma di mortal valore [...] 
Death [id.]

S'io son colei, ch'ogni mortal atterra [...]

\section{Hercules [id.]}

Ed ecco, al fin se' vinta [...]

\section{Death [id.]}

Solo mancava a le tue glorie, Alcide [...]

\section{Hercules [id.]}

Or vuoi donar quel che vietar non puoi? [...]

\section{Death [id.]}

Va' non andrai lunga stagion altero [...]

\section{Apollo [set to music by Vivarino]}

0 magnanimo eroe vinto hai la morte, solo al figlio di Giove è ciò permesso, Jupiter (Jove)

rendi viva ad Admetto la consorte,

ch'aura serba corona a te'l permesso.

[At this point the music stops]

\section{Hercules}

Andiam, o dal mio ardir, da le mie forze [...] etc.

By chance, I some years ago discovered the wordbook with the intermedi in the "Arturo Graf" library at the University of Turin..$^{30}$ Until that lucky day it had been impossible for twenty years for me to identify the source used by the composer: the lines represented a puzzle whose meaning remained obscure in the absence of the stanzas referring to the other characters.

The music of Vivarino is in true concertato style in the episode for Alcestis, where soprano and violins interact. In contrast, Apollo's monody is accompanied only by continuo except for the last lines, which are similarly sung with two violins. Each stanza, whose music is conceived as a mixture of arioso and recitative style, is followed by a "Sinfonia:" namely, a ritornello, played by the violins as if in a cantata. However, this is not a cantata with arias and recitatives; moreover, the monodic sections feature a dramatic texture in arioso style that is unlike the species of monody found in the Florentine or Roman operas that flourished during the first decade of the seventeenth century. Vivarino probably created, around 1624, verses and music in up-to-date style for Alcestis, while for Apollo he retained the music already written in response to Contarini's commission. The title Madrigali concertati is conservative and incorrect. As in the Nuove musiche $(1601,1614)$

${ }^{30}$ This example is now consultable online at archive.org/stream/image392TeatroOpal. 
of Giulio Caccini, the term "madrigal" refers to through-composed music, so that duets and trios turn into monodies with continuo.

Some complications occur in the distribution between the partbooks of the music for this intermedio. The Madrigali concertati come in four partbooks: Canto Primo; Canto Secondo; Basso; Basso Continuo. The monodies for Alcestis and Apollo, both printed with a figured bass, are for a soprano voice, which is included in the Canto Secondo partbook under the heading "A 3. Soprano e doi Violini” (pp. 26-33). The parts for first and second violins appear in the partbooks labelled Canto Primo (pp. 27-29) and Basso (pp. 11-13). The partbook for Basso Continuo, which contains an unbarred figured bass part, replicates the notes of the Basso that supports the soprano voice. Predictably, the continuo part for the ritornellos appears only in the Basso Continuo partbook (on p. 24). ${ }^{31}$

One final remark. Alcestis did not prove a very attractive subject for poets and musicians until the mid-seventeenth century. Only a few other versions from this period exist of Euripides's tragedy, which did not have the same wide diffusion as the story of Orpheus, the favourite myth in theatre and opera. The following is a short list of the works that have emerged from my survey of the topic:

- Giulio Salinero, Alceste, tragedia di Giulio Salinero, detto l'Abbandonato fra gli Accademici Accesi (Genova: eredi di Girolamo Bartoli, 1593).

- Scipione Agnelli, in a letter addressed to the Duke of Mantua (19 December 1616), written after Monteverdi's doubts expressed about Le nozze di Tetide, Alessandro Striggio reports that the poet Scipione Agnelli has written for Monteverdi a pathetic "libretto" entitled Congiunta d'Alceste et d'Ameto. ${ }^{32}$

- Melchiorre Zoppio, Admeto, tragedia del Caliginoso Melchiorre Zoppio (Bologna: Tebaldini, 1634). This tragedy was staged in Bologna (1626).

- $\quad$ Prospero Bonarelli, Alceste in Melodrami, cioè opere da rappresentarsi in musica del conte Prospero Bonarelli. Alla Serenissima Donna Vittoria Gran Duchessa di Toscana (Ancona: Marco Salvioni, 1647).

${ }^{31}$ An essay on Contarini's La finta Fiammetta, and the complete edition of its intermedi with the music of Vivarino is in preparation.

${ }^{32}$ Fabbri, Monteverdi, 150-151. 


\section{Bibliography}

Brunelli, Vitaliano. I teatri di Padova dalle origini alla fine del secolo XIX. Padova: Draghi, 1921.

Castronovo, Valerio. "Borghese Caffarelli, Scipione.” In Dizionario Biografico degli Italiani, vol. 12, Rome: Istituto dell'Enciclopedia Italiana, 1971. http://www.treccani. it/Portale/ricerche/searchBiografie.html.

Cavallini, Ivano. "Note biografiche e critiche su Innocenzo Vivarino e i Madrigali concertati del 1624.” Subsidia Musica Veneta 1 (1980): 39-76.

___ . "Nuove riflessioni sul madrigale drammatico." Recercare 23 (2011): 77-102.

Cavicchi, Adriano. "Immagini e forme dello spazio scenico nella pastorale ferrarese." In Sviluppi della drammaturgia pastorale nell'Europa del Cinque-Seicento, edited by Myriam Chiabò and Federico Doglio, 45-86. Rome: Torre d'Orfeo, 1991.

Contarini, Francesco. Francesci Contareni Thadaei patritii veneti fili, philosophiae, iuris utriusque et sacrae theologiae doctoris, de Deo et de his quae effluxerunt a Deo. Padua: Pasquati, 1594.

___ L L L finda ninfa favola pastorale di Francesco Contarini prencipe dell'Academia Serafica. Venice: Bolzetta 1598.

_-_ Madrigali di Francesco Contarini academico Olimpico e Ricovrato dedicati all'illustrissimo et reverendissimo sig. Federico Cornaro gran Comendator di Cipri, Abbate di Vidore e Chierico di Camera. Venice: Ciotti, 1601.

___ Oratione di Francesco Contarini per nome dell'Academia Ricovrata all'illustrissimo signor Tomaso Contarini, cavalier, conte del Zaffo, e podestà di Padova nella sua partenza. Padua: Bolzetta, 1609.

___ L L L finta Fiammetta favola pastorale di Francesco Contarini dedicata all'ill.mo et rev.mo sig. cardinal Scipione Borghesi. Venice: Dei, 1610.

___ L L f finta Fiammetta, favola pastorale di Francesco Contarini. Dedicata all'illustrissimo et reverendissimo signor cardinale Scipione Borghesi con gl'Intermedi aggiunti in questa seconda impressione. Venice: Dei, 1611.

___ Intermedi rappresentati nella finta Fiammetta di Francesco Contarini. Dedicati all'illustrissmo et eccellentissimo sig. Giovanni Mocenigo ambasciatore veneto a $n$. s. papa Paolo V. Venice: Dei, 1611.

_- - Intermedi rappresentati nella finta Fiammetta in Padoa. Di Francesco Contarini. Venice: Dei, 1611.

____ Isaccio tragedia. Al serenissimo Marcantonio Memmo doge di Venetia et all'eccellentissimo collegio dedicata. Venice: Ciotti, 1615.

___ Oratione di Francesco Contarini alla virtuosissima Academia Filarmonica di Verona nell'essere stato accettato Academico con alcune rime. Verona: Tamo, 1621. Fabbri, Paolo. Monteverdi. Translated by Tim Carter. New York: Cambridge University Press, 1994.

Ferazzoli, Illuminato. Fileno, favola boscareccia. Treviso: Zanetti, 1601.

Lo stato Marciano durante l'interdetto: 1606-1607. Edited by Gino Benzoni. Rovigo: Minelliana, 2008. 
Luisi, Francesco. "Musica e tragedia nel pensiero teorico del Cinquecento." Musica e Storia 7 (1999): 105-140.

___ Il Caritesio ovvero il convito delle grazie: studi sulla musica per il teatro e sull'iconografia musicale nel XVI secolo, edited by Ivano Cavallini, Patrizia Dalla Vecchia and Paolo Russo, 3-239. Padua: CLEUP, 2008.

Maggiolo, Attilio. I soci dell'Accademia Patavina dalla sua fondazione (1599). Padua: Il Prato, 2002.

Mangini, Nicola. "La tragedia e la commedia." In Il Seicento, vol. 4, bk. 1 of Storia della cultura veneta, edited by Girolamo Arnaldi and Manlio Pastore Stocchi, 297-326. Vicenza: Neri Pozza, 1983.

Osthoff, Wolfgang. Theatergesang und darstellende Musik in der italienischen Renaissance. 2 vols. Tutzing: Schneider, 1969.

Pirrotta, Nino. Li due Orfei: da Poliziano a Monteverdi. Torino: Einaudi, 1975.

Relazioni degli stati europei lette al Senato dagli ambasciatori veneti nel secolo decimosettimo, raccolte ed annotate da Nicolò Barozzi e Guglielmo Berchet. Serie 3. Venice: Naratovich, 1877-1888.

Rees, Katie. "Satyr Scenes in Early Modern Padua: Valeria Miani’s Amorosa speranza and Francesco Contarini's Fida ninfa." The Italianist 34 (2014): 23-53.

Serie cronologica dei vescovi di Adria compilata dal nob. de Lardi già procancelliere vescovile nella diocesi stessa con annotazioni. Edited by Francesco de' Lardi. Venice: Bonvecchiato, 1851.

Solerti, Angelo. "Laura Guidiccioni Lucchesini ed Emilio de' Cavalieri: i primi tentativi di melodramma." Rivista Musicale Italiana 9 (1902): 797-829.

Vecchi, Horatio. Selva di varia ricreatione [...] nella quale si contengono varij soggetti a 3, a 4, a 5, a 6, a 7, a 8, a 9 et a 10 voci, cioè madrigali, capricci, balli, arie, justiniane, canzonette, fantasie, serenate, dialoghi, un lotto amoroso, con una battaglia a diece nel fine. Venice: Gardano, 1590.

Vivarino, Innocentio. Madrigali concertati a due e tre voci et a voce con violini e sinfonie per cantar nel clavicembalo, chitarrone o altro simile strumento d'Innocentio Vivarino, organista nel Duomo d'Adria. Opera sesta. Venice: Alessandro Vincenti, 1624. 


\section{DVA NEZNANA PRIMERA TISKANE PRILOŽNOSTNE GLASBE V ITALIJANSKEM GLEDALIŠČU 16. IN 17. STOLETJA}

\section{Povzetek}

Čeprav je bilo v italijanskem gledališču 16. stoletja izvedeno ogromno enoglasne in polifone glasbe, je bil natisnjen le njen neznaten del. Vsaka priložnostna glasba, izvajana bodisi na odru bodisi med dejanji, se je pojmovala kot manj pomembna sestavina predstave, primerljiva s sceno ali razsvetljavo. V tem pogledu predstavljajo Firence izjemo. Po eni strani se je v Veliki vojvodini Toskani gledališče razumelo kot politično sredstvo za razkazovanje moči in bogastva, po drugi pa kot prostor, kjer se lahko manifestira občutek za sodobno gledališče - sodobni gledališki okus. Oživljanje firenškega gledališča danes ne predstavlja težav: besedila komedij in pastoral, njihovi scenariji, navodila za njihovo uprizoritev kot tudi njihova glasba, vse to se je objavljalo in širilo po vsej Italiji in na tujem. Nasprotno temu so bila mesta kot Mantova, Benetke, Ferrara, Rim in Neapelj, ki so bila enako udeležena v gledališkem dogajanju, pri objavljanju gledališke glasbe manj dejavna.

Sodobna muzikologija želi dognati logiko gledališke glasbe, in sicer preko analize razmerja med glasbo in besedilom, bolj natančno, preko analize razmerja med literarnimi deli dvornih pesnikov in partiturami (ali glasovnimi zvezki) skladateljev, delujočih v istem okolju. Za številne kompozicije pomanjkanje podatkov raziskovalcem žal preprečuje, da bi dognali, ali so se uporabljale v gledališču ali ne. V zvezi s tem problemom je zanimiva navedba polifone kompozicije Orazia Vecchija v pastoralni drami Fileno (1594) Illuminata Ferazzolija. Predstava tega dela je bila v kraju Lugo di Romagna, posvečena pa je bila Gesualdu da Venosi in Alfonsu Fontanelliju, ki sta bila oba plemiča in skladatelja. Kot je razvidno iz odrskega napotka (»Tutti cantano Oratio Vecchi sulla Selva«), je igro uvedel osemglasni dialog Ecco nuncio di gioia, vzet iz Vecchijeve zbirke Selva di varia ricreatione (1590), čemur je sledila pesem. Navedba zbora pastirjev in nimf je nenavadno pričevanje o gledališki rabi glasbe, ki je bila objavljena pred nastankom drame in ni imela z njo nobene zveze. V luči teorije dramskega dela je tak zaključek nepravilen, saj ga sestavljajo zbor, ki mu sledi intermedij in nato še ena nova zborovska točka.

Drugi doslej še nepoznani primer ponazarja težave, do katerih pride ob rekonstruiranju predstave na osnovi ohranjenih virov, oziroma ob sestavljanju dramskega besedila, intermedijev in glasbe v popolno celoto. V letih 1610-1611 je dramatik in filozof Francesco Contarini objavil pastoralo La finta Fiammetta, ki je bila z vrsto intermedijev uprizorjena v Padovi v pustnem času. To delo je bilo posvečeno kardinalu Scipionu Borgheseju, nečaku papeža Pavla V. Contarini je pozneje pripravil še drugo izdajo te iste pastoralne drame in jo ponovno posvetil istemu mecenu. Še več, drugo ločeno, a s prejšnjo povezano knjigo intermedijev je izdal pod okriljem ambasadorja svetega sedeža Giovannija Moceniga, verjetno za izvedbo v Benetkah. Drugi od štirih intermedijev (objavljenih kot Intermedi rappresentati nella finta Fiammetta) z naslovom La lotta di Hercole con la Morte vsebuje natančna odrska navodila. Zgodba je različica Evripidove tragedije Alkestida, ki pripoveduje o boju Herkula/Alkida s Smrtjo.

Situacija zahteva razmislek v treh smereh. Prvič je treba izpostaviti, da v Benetkah ni bilo običajno, da bi se tiskali intermediji in glasba skupaj, tako da je primer tiska La finta 
Fiammetta že sam po sebi izjemen, četudi ga povežemo s političnimi cilji: spravo med Rimom in Benetkami po diplomatski vojni 1606-1607. Drugič velja omeniti, da se sama zgodba o Alkestidi pred sredino 17. stoletja pesnikom in glasbenikom ni zdela posebno privlačna. Tretje opažanje pa je, da je Innocentio Vivarino Contarinijeve verze uglasbil na zelo zapleten način. Ta beneški skladatelj je intermedij o Alkestidi objavil v svoji zbirki Madrigali concertati a due e tre voci et a voce con violini e sinfonie (1624), in sicer kot solistično dramatično epizodo z medigrami za dve violini in kontinuo. Ne da bi bilo omenjeno Contarinijevo pesniško delo, vsebuje zadnji del te knjige madrigalov monodijo, namenjeno Alkestidi in Apolonu, ki razpravljata o Herkulovem boju in zmagi. Vivarino je vzel le del Contarinijevega besedila, in sicer verze, ki se nanašajo na Apolona, ki jim je dodal eno kitico za Alkestido. To se je skladalo s pravilom - ki je veljalo vse od Polizianove Favole di Orfeo, in sicer, da je bilo petje dovoljeno le bogovom. To je tudi razlog, zakaj Vivarino ni uglasbil besed, ki jih izgovarjata Herkul in Smrt. 